\title{
PENGEMBANGAN VARIATIF RANCANGAN ANTENA PANEL MICROSTRIP TAPERED PATCH DALAM SISTEM KOMUNIKASI WI-FI
}

\author{
Putu Artawan ${ }^{1)}$, Iwan Suswandi ${ }^{2)}$ dan Ketut Purnamawan ${ }^{3)}$ \\ 1)2) Jurusan Pendidikan Fisika Fakultas MIPA \\ 3) Jurusan Teknik Informatika FTK \\ Universitas Pendidikan Ganesha \\ Singaraja, Indonesia
}

Email: scientya@yahoo.com, tutpurna@yahoo.com

\begin{abstract}
Abstrak
Pada penelitian ini dilakukan pengembangan rancangan antena microstrip tapered patch untuk dilakukan pengukuran parameternya sebagai karakteristik dari antena Microstrip. Penelitian ini sebagai pengembangan variatif rancangan untuk memperoleh hasil yang lebih optimal. Metode eksperiment dilakukan dalam penelitian ini. Tahap pengerjaanya yaitu membuat desain rancangan antena sesuai persamaan yang ada yang kemudian dirancang dengan metode UV Photoresist laminate. Hasil rancangan antena diukur untuk mendapatkan karakteristik sebagai parameter antena meliputi frekuensi (bandwidth), SWR, VSWR, koofesien refleksi, pola radiasi dan penguatan (gain) serta nilai HPBW. Nilai-nilai tersebut mencerminkan karakter dari sebuah antena sebagai parameter antena yang layak diimplementasikan dalam sistem komunikasi internet dengan sistem wi-fi. Hasil penelitian ini meliputi: nilai lebar pita (bandwidth) $=0.21 \mathrm{GHz}, V S W R=1,23, S W R=1,79$, return loss $=$ $20,00 \mathrm{~dB}$, koofesien refleksi $=0,10$ dan grafik pola radiasi dengan penguatan (gain) $=17 \mathrm{~dB}$ (polarisasi vertikal), $20 \mathrm{~dB}$ (polarisasi horizontal). Nilai Half Power Beamwidth (HPBW) $82^{0}$ untuk pola radiasi vertikal dan pola radiasi horizontal. Kesalahan (error) hasil pengukuran $0,12 \%$ dengan keseksamaan $99,88 \%$. Hasil ini memberikan indikasi sebagai rancangan antena yang layak untuk sistem komunikasi wi-fi. Penelitian ini sebagai salah satu aplikasi ilmu Fisika dalam dunia teknologi informasi dan diharapkan dapat bermanfaat sebagai dinamika wahana salah satu produk penerapan ilmu Fisika dalam bidang Teknologi Informasi.
\end{abstract}

Kata Kunci: Microstrip Tapered Patch, Wi-fi, UV Photoresist laminate.

\begin{abstract}
In this research, design development tapered microstrip patch antennas were designed for measurement parameters to determine the characteristics of the antenna Microstrip. This study varied as the development plan to obtain more optimal results. Methods experiments was applied in this study. The procedure included; creating a draft design of the antenna according to the equation which was then designed by the method of UV photoresist laminate. The results of the design of the antenna was measured to obtain the characteristics of the antenna parameters include frequency (bandwidth), SWR, VSWR, koofesien reflection, radiation pattern and gain (gain) and the value of HPBW. These values reflected the character of an antenna as a decent antenna parameters implemented in the Internet communication system with wi-fi system. The results of this study include: the value of wide-band (bandwidth) $=0: 21 \mathrm{GHz}, \mathrm{VSWR}=1.23, \mathrm{SWR}=1.79,=-20.00 \mathrm{~dB}$ return loss, reflection koofesien $=0.10$ and chart patterns by strengthening radiation (gain) $=17 \mathrm{~dB}$ (vertical polarization), $20 \mathrm{~dB}$ (horizontal polarization). Value Half Power Beamwidth (HPBW) 820 for the radiation pattern of vertical and horizontal radiation pattern. Error (error) measurements of $0.12 \%$ with $99.88 \%$ accuracy. These results gave an indication as
\end{abstract}


appropriate antenna design for wi-fi. communications systems This study as one of the world science applications in physics and information technology was expected to be useful as a dynamic vehicle for one of the products applying the science of physics in the field of Information Technology.

Kata Kunci: Microstrip Tapered Patch, Wi-fi, UV Photoresist laminate.

\section{PENDAHULUAN}

Teknologi informasi semakin menggerogoti dunia hampir ke segala aspek kehidupan. Dengan kecepatan yang begitu tinggi akses informasi dan komunikasi menjadikan dunia semakin sempit. Informasi dan komunikasi dari waktu ke waktu begitu cepat dan senantiasa berkembang. Kemajuan yang begitu pesat tersebut tidak terlepas dari peran perangkat teknologi yang kini semakin berkembang yaitu salah satunya adalah perangkat jaringan atau Antena. Antena adalah suatu komponen penting dalam proses transceiver energi gelombang elektromagnetik sehingga menjadi satu kesatuan teknologi yang terintegrasi dengan baik. Antena sebagai perangkat yang menentukan performansi jaringan memiliki peran sangat penting hingga proses transfer data akibat perkembangan perangkat fisik yang begitu menjamur hingga munculnya jaringan fisik dengan dan tanpa kabel. Trend perangkat yang berkembang dan dimanfaatkan begitu luas dewasa ini adalah perkembangan sistem komunikasi tanpa kabel yaitu yaitu sistem komunikasi wireless fidelity yang lebih dikenal dengan sistem komunikasi Wi-Fi. Sistem komunikasi wi-fi merambah dari kalangan atas hingga ke pelosok-pelosok hingga bisa dinikmatinya akses internet yang begitu cepat dan murah. Dalam membangun sistem tersebut antena sangatlah berperan penting sebagai bagian utama dari proses transmisi. Antena berperan tidak hanya sebagai pemancar namun juga sebagai penerima gelombang yang ditransmisikan kedalam suatu sinyal dalam proses transceiver gelombang. Antena memiliki peran sentral dalam arus lalu lintas teknologi informasi.

Pada penelitian ini didesain pengembangan rancangan antena yang variatif dengan spesifikasi yang sesuai dengan karakteristik suatu antena sebagai perangkat dalam proses transfer energi dalam sistem komunikasi internet dengan sistem wi-fi. Penelitian ini adalah pengembangan dari penelitian sebelumnya yang sudah pernah dirancang dengan karakteristik desain yang bervariasi hingga mendapatkan hasil yang lebih optimal sebagai perangkat antena yang mendukung sistem komunikasi wi-fi. Diharapkan antena yang dirancang sebagai pengembangan pada penelitian ini memperoleh hasil pengukuran yang lebih optimal dalam artian antena yang dirancang lebih efisien dan mendapatkan kapasitas yang lebih besar, bandwidth yang lebih lebar, VSWR yang kompatibel dan return loss yang lebih kecil serta dengan penguatan (gain) yang lebih besar. Antena yang dirancang pada penelitian ini adalah antena mikrostrip sistem panel variatif. Dirancang untuk mendapatkan hasil yang lebih optimal yang memenuhi karakteristik antenna yang berada pada range wifi.

Beberapa rancangan penelitian sebelumnya telah mendapatkan hasil sebagai karakteristik antena pendukung komunikasi wi-fi antara lain: dirancang antena panel $2 \times 2$ dengan hasil penguatan $19 \mathrm{~dB}$ (Artawan, 2010a), antena panel $2 \times 4$ dengan hasil penguatan 21,93 dB. (Artawan, 2011), dengan panel $4 \times 4$ dihasilkan penguatan 22,07 dB (Artawan, 2011). Peneliti lain dalam Aswoyo, 2000 juga pernah melakukan penelitian sejenis dengan rancangan panel 4 × 4 dihasilkan rancangan dengan hasil penguatan antara 9,5 sampai dengan 22,0 dB. Dari hasil tersebut yang dilakukan oleh peneliti dan peneliti lain, peneliti berupaya untuk mengembangkan rancangan antena sejenis dalam sistem 
panel yang variatif hingga menghasilkan penguatan yang lebih besar dan hasil yang lebih optimal. Cara yang dilakukan adalah dengan menambah jumlah larik dalam sistem panel antena yang dirancang. Untuk menghasilkan bandwidth yang lebih lebar dan penguatan (gain) yang lebih besar diupayakan dirancang antena mikrostrip dengan jumlah larik yang lebih banyak (Edward, Terry 1991). Disamping menambah jumlah larik, diupayakan ukuran atau dimensi dari antena yang dirancang lebih kecil sehingga lebih mudah untuk dibawa kemana-mana.

$$
\text { Penelitian ini dilakukan sebagai }
$$

pengembangan dan penyempurnaan penelitian sebelumnya sehingga mampu mengasilkan karakteristik antena yang lebih optimal sebagai pendukung perangkat komunikasi internet dengan sistem wi-fi. Penelitian ini juga memberikan cakrawala luas dan membuka wawasan dinamika informasi komunikasi yang begitu bermanfaat dalam perkembangan teknologi informasi utamanya aplikasi dari ilmu Fisika dalam dunia informasi dan komunikasi. Penelitian ini sebagai cermin bahwa IImu Fisika memiliki kontribusi yang luar biasa terhadap perkembangan dan kemajuan teknologi terutama dalam perkembangan sistem informasi komunikasi. Ilmu Fisika bisa diterapkan dan mempunyai manfaat yang sangat besar dalam kehidupan seharihari.

\section{METODE}

Metode pada penelitian ini adalah metode eksperiment. Adapun tahapantahapan penelitian yang dilakukan adalah sebagai berikut: 1) Analisis antena. Analisis antena dilakukan yaitu pada bagian mikrostrip line dan antena patch. Tahap 2) Penghitungan. Penghitungan yang dimaksud adalah penghitungan dimensi rancangan/desain secara manual dengan persamaan-persamaan karakteristik parameter antena untuk menghasilkan desain/rancangan yang nantinya akan dirancang. 3) Fabrikasi/Pembuatan Rancangan. Pada proses pengerjaannya (fabrikasi) dilakukan dengan metode UV Photoresist Laminate. 4) Pengukuran dan Analisis. Setelah dihasilkan suatu antena, antena diukur dan dianalisis untuk mendapatkan karakteristik antena sebagai parameter apakah antena yang dihasilkan bisa diimplementasikan untuk sistem komunikasi wi-fi.

Secara rinci berikut disajikan bagan tahapan-tahapan penelitian dalam suatu diagram alir penelitian:

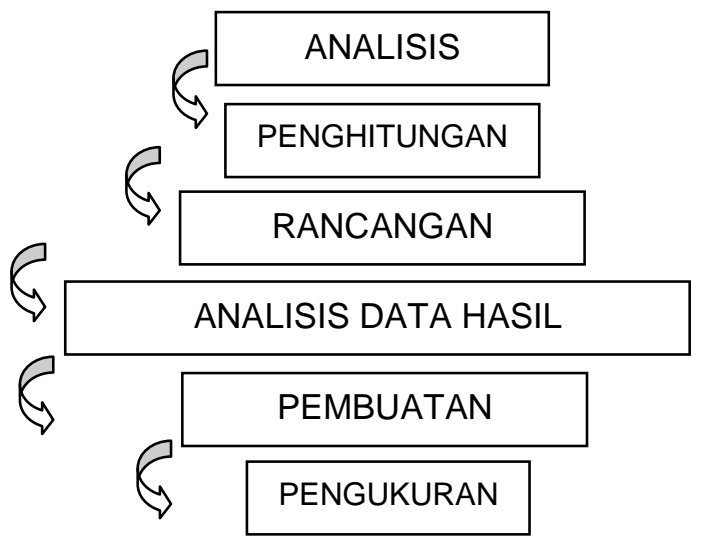

Gambar 1: Diagram Alir Penelitian

\section{Analisis Antena}

Analisis antena microstrip dilakukan dengan menggunakan persamaanpersamaan untuk menentukan dimensi sebagai parameter dari antena dan karakterisasi dari antena yang dirancang sesuai dengan yang sudah dipaparkan pada kajian pustaka. Penentuan arah medan elektromagnetik dengan dimensi ukuran yang tepat dan pencatuan dilakukan berdasarkan anilisis persamaan karakteristik antena. Hasil penelitian sebelumnya juga sebagai acuan analisis untuk menghasilkan bandwidth yang lebih lebar dan dengan penguatan (gain) yang lebih besar sesuai dengan tujuan penelitian yang diinginkan. 


\section{Rancangan Antena}

Berikut disajikan rancangan Antena Microstrip yang sudah dan akan difabrikasi:


Gambar 2: Rancangan Antena Microstrip Tapered Patch

\section{Fabrikasi / Pembuatan Antena}

Metode yang dilakukan pada saat perancangan antena adalah dengan metode UV Photoresist Laminate. Prosesnya dilakukan dengan beberapa tahap, antara lain: a) Tahap pencetakan (printing), b) Tahap pencahayaan (exposure), c) Tahap pendinginan (Anneling), d) Tahap pemasangan konektor dan reflektor, e) Tahap pengukuran. Berikut disajikan prosesnya:



Gambar 3: Proses Fabrikasi Dengan UV Photoresist Laminate

(a). Pencetakan (Printing) (b) Pencahayaan (exposure) (c). Pendinginan (Anneling), (d) Pemasangan konektor dan reflektor. (a) Desain rancangan antena dibuat dengan program Corel Draw atau program/software desain yang lain yang selanjutnya dicetak layout ke transparan plastik film dengan laser printer. (b). Layout diletakkan diatas bahan $F R_{4}(P C B)$ yang sudah disiapkan sesuai ukuran yang dirancang, kemudian bahan $F R_{4}(P C B)$ dimasukkan kedalam box cahaya untuk melakukan pencahayaan dan diletakkan dibawah sinar Ultraviolet (UV). Penyinaran dilakukan selama kurang lebih 2 menit. Pada proses penyinaran area yang gelap akan menjadi area tembaga dan yang transparan akan hilang. Bagian yang gelap tidak akan ada cahaya UV yang bisa tembus. (c). Proses pendinginan (anneling) dilakukan karena suhu setelah proses penyinaran masih cukup tinggi/panas sekitar 30-40 derajat celcius. Setelah kurang lebih 10 menit, selanjutnya $P C B$ dimasukkan kedalam wadah yang berisi cairan Natrium Hidroksida $(\mathrm{NaOH}) \pm 1 / 2$ liter untuk dibersihkan dan kemudian dibersihkan lagi dengan air sampai $P C B$ yang sudah tercetak benar-benar bersih. (d). Setelah selesai, selanjutnya dilakukan pemasangan konektor $n$-female dengan impedansi $50 \Omega$. Ujung konektor disambungkan dengan kabel koaksial hingga ujungnya muncul pada permukaan pitchline yang selanjutnya dilakukan penyolderan agar konektor benarbenar terhubung dengan bagian pitchline. Pemasangan konektor bersamaan dengan pemasangan reflektor. Fungsi reflektor disini adalah agar sinyal yang diterima bisa ditransmisikan dengan lebih optimal (e). Tahap pengukuran Antena Microstrip. Pengukuran dilakukan di Laboratorium Fisika dengan menggunakan alat ukur Network Analyzer, sedangkan pola radiasi yang dihasilkan pengukurannya dilakukan di alam bebas, tempat lapang yang terbebas dari faktor pantulan seperti tembok atau tanah.

\section{Pengukuran}

Pengukuran dilakukan untuk mendapatkan parameter dari antena yang Jurnal Sains dan Teknologi | 166 
dirancang, meliputi frekuensi dan penguatan (gain) yang secara implisit mendapatkan parameter sebagai karakteristik dari antena yang dirancang. Pengukuran dilakukan dibagi menjadi dua tahap yaitu tahap pertama dilakukan dengan Network Analyzer untuk mengetahui frekuensi dan SWR, tahap kedua setelah data frekuensi diperoleh dan dianalis antena kembali diukur dengan perangkat detektor untuk menghasilkan pola radiasi serta HPBW (Half Power Beam Width).

\section{HASIL DAN PEMBAHASAN}

Setelah dilakukan fabrikasi sesuai dengan metode yang diuraikan diperoleh hasil sebagai berikut:

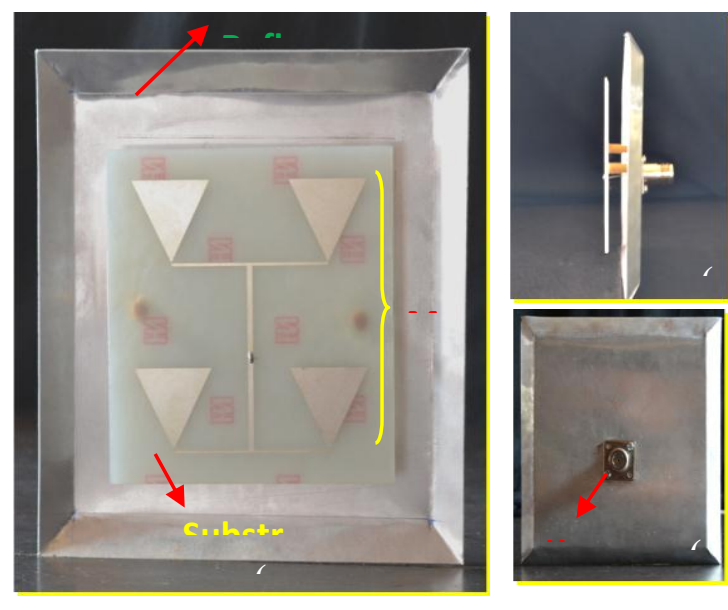

Gambar 4: Hasil Fabrikasi Antena Mikrostrip Tapered Patch

Antena yang sudah difabrikasi diukur dengan Network Analyzer untuk mendapatkan nilai frekuensi dan SWR. Berikut rancangan pengukuran antena yang sudah difabrikasi dengan menggunakan Network Analyzer:

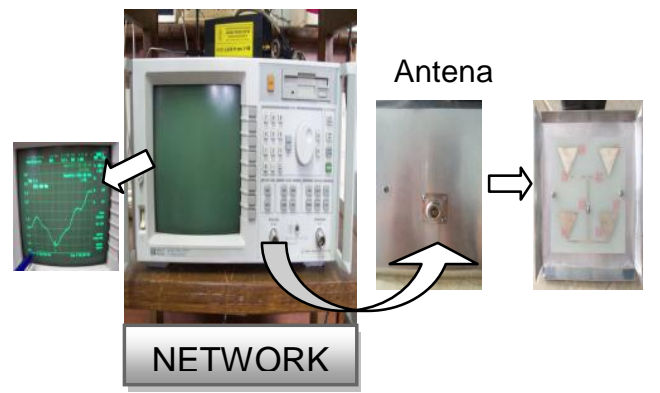

Gambar 5: Pengukuran dengan
Network Analyzer

Selanjutnya nilai frekuensi dan SWR yang diperoleh dari hasil pengukuran dianalisis untuk mendapatkan karakteristik lain dari antena seperti VSWR, return loss dan koofesien refleksi.

Tabel 4.1 Data Hasil Pengukuran

\begin{tabular}{|c|c|c|c|c|}
\hline $\begin{array}{c}\text { Band } \\
\text { width } \\
(\mathrm{GHz})\end{array}$ & SWR & $\begin{array}{c}\text { VSW } \\
\mathrm{R}\end{array}$ & $\begin{array}{c}\text { Return } \\
\text { loss } \\
(\mathrm{dB})\end{array}$ & $\begin{array}{c}\text { Koofesi } \\
\text { en } \\
\text { Refleksi }\end{array}$ \\
\hline 0.21 & 1,79 & 1,23 & $-20,00$ & 0,10 \\
\hline
\end{tabular}

Dari Tabel 4.1 dapat diketahui bahwa daerah frekuensi kerja antena yang difabrikasi berada pada range 2,19 - 2,40 $\mathrm{GHz}$ dengan bandwidth $0.21 \mathrm{GHz}$. Ini berarti bahwa antena yang difabrikasi bisa diaplikasikan untuk komunikasi wi-fi dengan frekuensi 2,4 GHz. Nilai SWR 1,79 dan VSWR 1,23 menunjukkan bahwa gelombang yang dipantulkan balik kecil, sebagian besar gelombang ditransmisikan. Hal ini mengindikasikan bahwa kinerja antena semakin baik karena nilai SWR dan VSWR yang bisa diterima berada pada rentang $1-2$. Nilai return loss $-20,00 \mathrm{~dB}$ menunjukkan bahwa sinyal yang dipantulkan semakin kecil dan sebaliknya sinyal yang diteruskan semakin besar. Dengan nilai return loss yang semakin kecil kinerja antena semakin bagus. Nilai return loss yang dapat diterima untuk komunikasi dua arah $<-15 \mathrm{~dB}$. Dengan koofesien refleksi 0,10 berarti bahwa hampir semua daya dari tegangan input dipancarkan. Koofesien 
refleksi mengindikasikan seberapa besar daya pantul yang dimiliki oleh sebuah antena. Koofesien refleksi yang mendekati 0 menunjukkan bahwa kinerja antena yang difabrikasi baik.

Selanjutnya data yang diperoleh dari hasil pengukuran dianalisis dengan menggunakan program Matlab (Matrik Laboratory Program) untuk menghasilkan grafik hubungan antara frekuensi dengan VSWR dan grafik hubungan antara frekuensi dengan return loss.

Berikut disajikan grafik hubungan frekuensi dengan VSWR:

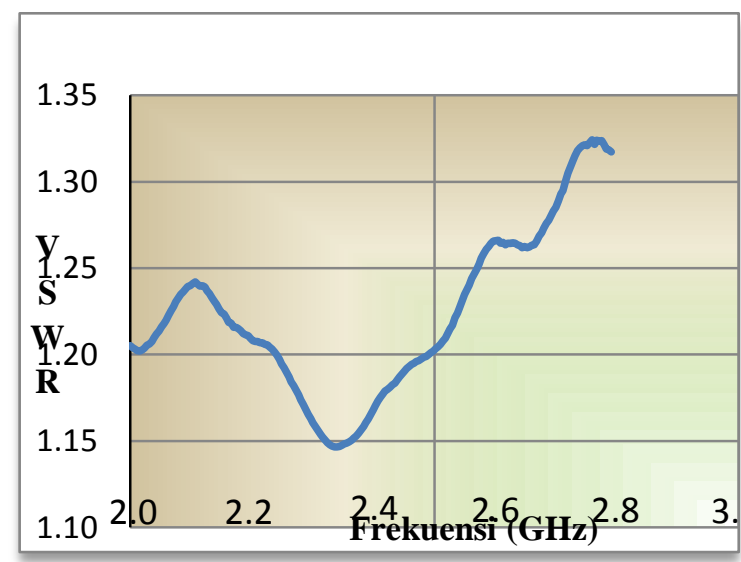

Gambar 6: Hubungan Frekuensi dengan VSWR

Pada grafik hubungan antara frekuensi dan VSWR terlihat bahwa antena yang difabrikasi berada pada daerah frekuensi kerja 2,19-2,40 GHz dengan VSWR 1,23. $\mathrm{Hal}$ ini menunjukkan bahwa antena yang difabrikasi untuk daerah frekuensi tersebut bisa diaplikasikan untuk komunikasi wi-fi dengan frekuensi 2,4 GHz. Nilai $V S W R$ yang diperoleh mengindikasikan bahwa antena yang difabrikasi memiliki kinerja yang baik. Artinya sebagian besar gelombang ditransmisikan dan sedikit yang dipantulkan. Secara teori nilai $V S W R$ yang bisa diterima sebagai indikasi antena yang baik memiliki nilai $1<V S W R<2$. Semakin kecil atau mendekati 1 nilainya semakin bagus.

Berikut disajikan grafik hubungan frekuensi dengan return loss:

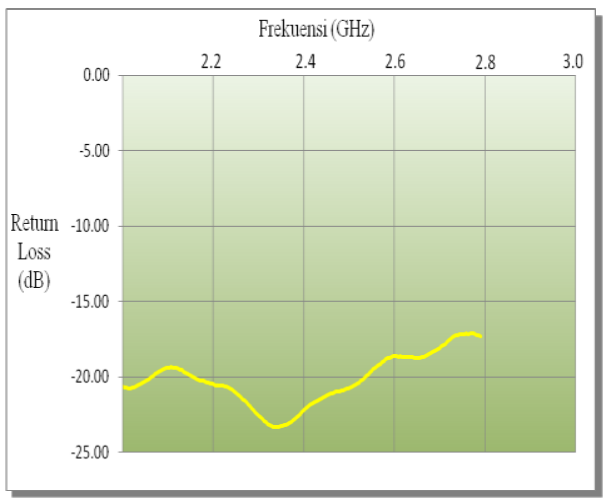

Gambar 7: Hubungan

Frekuensi dengan Return Loss

Pada grafik hubungan antara frekuensi dengan return loss terlihat bahwa antena yang difabrikasi bekerja pada daerah frekuensi 2,19 - 2,40 $\mathrm{GHz}$ dengan nilai return loss $-20,00 \mathrm{~dB}$. Nilai return loss pada Gambar 7 mengindikasikan bahwa antena yang dirancang memiliki nilai return loss yang diterima sebagai karakter antena yang baik karena nilainya $<-15 \mathrm{~dB}$. Nilai ini adalah kebalikkan dari nilai penguatan yang dihasilkan.

Pengukuran pola radiasi dilakukan untuk mengetahui ke arah mana antena dihadapkan untuk mendapatkan intensitas sinyal yang baik.

Total power yang digunakan pada antena pemancar sebesar $18 \mathrm{~dB}+25 \mathrm{dBm}=43 \mathrm{~dB}$. Pada antena monopol power edimax wi-fi yang digunakan $=100 \mathrm{~mW}=20 \mathrm{dBm}$. Sehingga total power sebagai acuan pengukuran $=43 \mathrm{~dB}+20 \mathrm{~dB}=63 \mathrm{~dB}$.

Pengukuran pola radiasi dilakukan dengan rancangan sebagai berikut: 


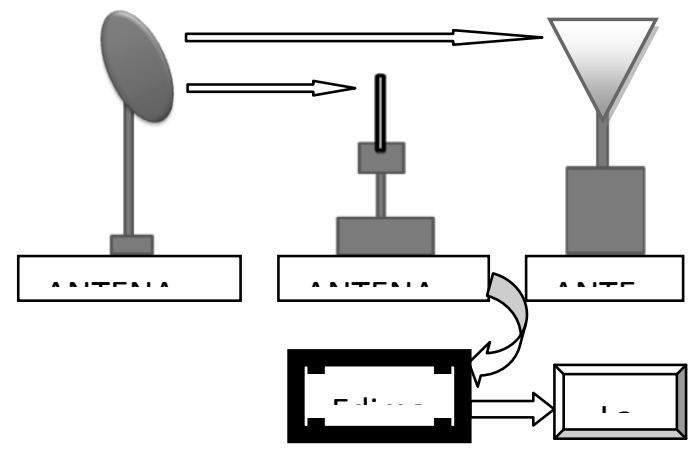

Gambar 4.6: Rancangan Pengukuran Pola Radiasi

Data pola radiasi diperoleh dengan memutar antena mikrostrip tapered patch ke arah vertikal dan horizontal dengan pergeseran sudut $5^{0}$, diarahkan sejajar terhadap antena monopol. Data yang diperoleh muncul pada laptop yang programmnya sudah disetting untuk gambar saat pengukuran pola radiasi:
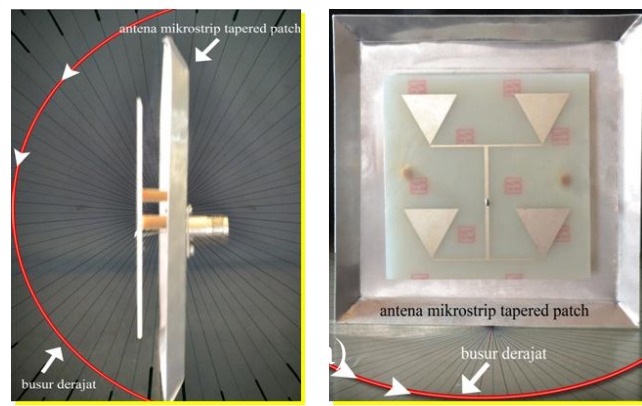

Gambar 8: Pengukuran Pola Radiasi

(a) Arah Vertikal dan (b) Horisontal

Gambar (a) antena diputar ke arah vertikal dimulai dari sudut $0^{0}$ kemudian diputar dengan pergeseran sudut $5^{0}$ begitu seterusnya sampai $360^{\circ}$. Pada laptop dicatat hasil sinyal yang diterima setiap perputaran dalam satuan decibels (dB). Begitu juga pada gambar (b) dengan cara yang sama namun antena diputar ke arah horizontal.

Dari data yang dicatat, selanjutnya data dianalisis dengan menggunakan program
Matlab (Matrik Laboratory Program). Hasilnya berupa grafik pola radiasi, sebagai berikut:


Gambar 9: Pola Radiasi

(a) Arah Vertikal dan (b) Horizontal

Dari grafik yang dihasilkan dapat disimpulkan bahwa pola radiasi yang dihasilkan baik pada arah vertikal maupun pada arah horizontal adalah pola radiasi radial. Artinya intensitas sinyal yang diperoleh pada arah tersebut bernilai maksimal.

Diperoleh nilai penguatan (gain) pola radiasi arah vertikal sebesar $18 \mathrm{~dB}$ dan pola radiasi arah horizontal sebesar $19 \mathrm{~dB}$. Semakin besar nilai penguatan (gain) yang diperoleh kinerja antena semakin baik. Nilai ini mengindikasikan nilai return loss yang kecil. Penguatan sebesar $17 \mathrm{~dB}$ dan $20 \mathrm{~dB}$ setara dengan nilai return loss $-17 \mathrm{~dB}$ dan $20 \mathrm{~dB}$. Pada hasil pengukuran diperoleh nilai return loss sebesar $-20,00 \mathrm{~dB}$. Perbedaan hasil ini mungkin disebabkan oleh adanya faktor pantulan disekitar tempat pengukuran saat pengambilan data pola radiasi.

Selanjutnya dari grafik tersebut diperoleh nilai Half Power Beamwidth (HPBW) dari antena yang difabrikasi. Diperoleh nilai $H P B W$ untuk pola radiasi vertikal dan horizontal $82^{\circ}$. Nilai $H P B W$ menyatakan nilai pengarahan terhadap pola radiasi dari antena yang diukur untuk mendapatkan intensitas sinyal yang maksimal. 
Dari nilai penguatan (gain) yang diperoleh dapat ditentukan nilai efisiensi radiasi dari masing-masing penguatan yang dihasilkan, yang berhubungan dengan direktivitas suatu antena. Nilai efisiensi yang diperoleh untuk pola radiasi vertikal 0,28 dan pola radiasi horizontal 0,31.

Nilai karakteristik antena antara lain: frekuensi, VSWR, SWR, koofesien refleksi ( $\Gamma)$ dan return loss (RL) yang dihitung dengan program perhitungan VB. 6 hasilnya disajikan pada Tabel 4.2.

Tabel 1 Data Hasil Perhitungan

Berikut disajikan tabel hasil pengukuran dengan hasil perhitungan:

\begin{tabular}{|c|c|c|c|c|}
\hline $\begin{array}{c}\text { FREKUEN } \\
\text { SI (GHz) }\end{array}$ & $\begin{array}{c}\text { VS } \\
\text { WR }\end{array}$ & SWR & $\begin{array}{c}\text { RL } \\
\text { (dB) }\end{array}$ & Г \\
\hline 2,4 & 1,25 & 1,94 & $-19,04$ & 0,11 \\
\hline
\end{tabular}

Tabel 2 Data Hasil Pengukuran dan Perhitungan

\begin{tabular}{|c|c|c|c|c|c|}
\hline HASIL & $\begin{array}{c}\mathbf{f} \\
(\mathbf{G H z})\end{array}$ & $\begin{array}{c}\text { VS } \\
\text { WR }\end{array}$ & $\begin{array}{c}\text { SW } \\
\mathbf{R}\end{array}$ & $\begin{array}{c}\mathbf{R L} \\
(\mathbf{d B})\end{array}$ & $\mathbf{\Gamma}$ \\
\hline $\begin{array}{l}\text { PENGU } \\
\text { KURAN }\end{array}$ & $2,19-$ & 1,23 & 1,79 & $-20,00$ & 0,10 \\
\hline $\begin{array}{l}\text { PERHIT } \\
\text { UNGAN }\end{array}$ & 2,4 & 1,25 & 1,94 & $-19,04$ & 0,11 \\
\hline
\end{tabular}

Dari Tabel 2 ditunjukkan bahwa terdapat perbedaan hasil karakteristik dari antena yang difabrikasi antara data hasil pengukuran dengan data hasil perhitungan. Perbedaan ini tidak terlalu signifikan karena masih berada pada rentang atau nilai yang masih bisa diterima sebagai syarat karakteristik antena yang baik untuk komunikasi wi-fi 2,4 GHz.

Ralat sistimatik diperoleh dengan mengetahui kalibrasi alat yang digunakan dalam proses pengukuran. Data untuk kalibrasi alat yang digunakan Network Analyzer HP8712 C (Output power level accuracy $\pm 1 d B$, frequency accuracy \pm $5 p p m)$. Artinya alat yang digunakan untuk pengukuran memiliki keakuratan power \pm $1 \mathrm{~dB}$ dan keakuratan frekuensi $\pm 5 \mathrm{ppm}$. Tidak dilakukan standarisasi dengan alat lain, namun keakuratan alat bisa diketahui dengan membandingkan hasil yang diperoleh dengan hasil perhitungan secara numerik.

Dengan menggunakan metode ralat kebetulan diperoleh hasil kesalahan $0,12 \%$ dengan kebenaran/keseksamaan 99,88\%. Hasil ini menunjukkan tingkat presisi yang tinggi dari alat ukur yang digunakan. Hal ini disebabkan oleh beberapa faktor seperti kalibrasi alat yang digunakan, sensitivitas alat dan juga faktor luar yang memberikan pengaruh terhadap hasil pengukuran tersebut.

\section{SIMPULAN DAN SARAN SIMPULAN}

Dari hasil dan analisis data yang diperoleh dapat disimpulkan bahwa: Fabrikasi dan karakterisasi antena mikrostrip tapered patch untuk komunikasi wi-fi pada frekuensi 2,4 GHz sudah dilakukan. Diperoleh hasil pengukuran karakteristik dari antena mikrostrip tapered patch yang dirancang meliputi nilai lebar pita (bandwidth) $=0.21$ $\mathrm{GHz}, \quad V S W R=1,23, S W R=1,79$, return loss $=-20,00 \mathrm{~dB}$, koofesien refleksi $=0,10$ dan grafik pola radiasi dengan penguatan (gain) $=17 \mathrm{~dB}$ (polarisasi vertikal), $20 \mathrm{~dB}$ (polarisasi horizontal). Nilai Half Power Beamwidth (HPBW) $82^{\circ}$ untuk pola radiasi vertikal dan pola radiasi horizontal. Kesalahan (error) hasil pengukuran 0,12\% dengan keseksamaan 99,88\%. Telah dibuat program (software) untuk menghitung Impedansi dan karakteristik antena mikrostrip tapered patch (VSWR, SWR, return loss dan koofesien refleksi) sesuai parameter-parameter yang ada dengan program Visual Basic.6. 


\section{SARAN}

Pengukuran untuk mendapatkan nilai frekuensi dan karakteristik antena yang difabrikasi dengan menggunakan Network Analyzer hendaknya dilakukan di ruang kedap (chamber). Saat pengukuran pola radiasi diupayakan dilakukan pada kondisi yang lebih ideal, ditempat yang jauh dari faktor-faktor yang menyebabkan adanya pantulan dan noise. Diharapkan juga kepada peneliti selanjutnya untuk mencoba merancang dengan dimensi yang optimum dan array yang lebih banyak sehingga diharapkan dapat diperoleh hasil yang lebih optimal.

\section{UCAPAN TERIMA KASIH}

Terimakasih disampaikan kepada Lembaga Penelitian UNDIKSHA sebagai fasilitator dan telah berkontribusi dalam pendanaan melalui DIPA UNDIKSHA dengan SPK No: 132/UN48.14/PL/2012, Dr Yono Hadi Pramono,M.Eng (Dosen Optoelektronika ITS surabaya) sebagai inspirator dalam ide untuk kelanjutan penelitian ini.

\section{DAFTAR PUSTAKA}

Artawan. (2011), Fabrikasi dan Karakterisasi Antena Mikrotrip Tapered Patch Untuk Aplikasi Antena Panel Pada Frekuensi 2,4 GHz. Tesis Magister, Jurusan Fisika, Fakultas Matematika dan IImu Pengetahuan Alam, Institut Teknologi Sepuluh Nopember (ITS), Surabaya.

Artawan, Hadi Pramono, Yono. (2010a), Perancangan Antena Panel Mikrostrip Horn Array 2x2 Untuk Komunikasi Wi-fi Pada Frekuensi 2,4 GHz. Prosiding Simposium Fisika Nasional (SFN), ITS, Surabaya.

Artawan, Hadi Pramono, Yono. (2010b), Perancangann Antena Panel Mikrostrip Horn Array 2x2 Utuk Komunikasi Wi-fi Pada Frekuensi 2,4 GHz. Prosiding Seminar Nasional MIPA, Universitas Negeri Malang, Malang.
Artawan, Hadi Pramono, Yono. (2010c), Perancangan Antena Mikrostrip Horn Untuk Aplikasi Antena Panel Pada Frekuensi 2,4 GHz. Prosiding Seminar Nasional Teknologi Informasi (SNTI), Universitas Tarumanegara, Jakarta.

Balanis, C.A. (1997), Antena Theory Analysis and Design, Second Edition, John Wiley and Sons, New York.

Edward, Terry. (1991), Foundation For Microstrip Circuit Design. Knaresborough England.

Hadi Pramono, Yono. (2002a), Analisa Respon Frekuensi Antena Mikrostrip. Prosiding Seminar Nasional Fisika dan Aplikasinya. ITS, Surabaya.

Hadi Pramono, Yono. (2002b), Analisa Karakteristik Antena CPW Slot dan Patch dengan FDTD. Prosiding Seminar Nasional Fisika dan Aplikasinya. ITS, Surabaya.

Hadi Pramono, Yono. (2005), Karakterisasi Antena Mikrostip Patch $3 \mathrm{GHz}$ Secara Simulasi FDTD (Finite Difference Time Domain) Dan Eksperimen. Jurnal Fisika. Institut Teknologi Sepuluh Nopember. Surabaya.

Hadi Pramono,Yono. (2009), Prototipe Antenna Bi-Mikrostrip tapered patch Dengan Dua Arah Pola Radiasi Dan Satu Feeding Monopole Beroperasi Pada Freq.2,4 GHz. Prosiding T.Informatika, UPN. Yogyakarta.

Hidayah, Ifa. (2009), Desain dan Fabrikasi Antena Bi-Mikrostrip tapered patch Dengan Dua Arah Radiasi dan Satu Feeding Monopole Untuk Komunikasi Wi-fi. Tesis Magister. Institut Tekologi Sepuluh Nopember. Surabaya.

Hund, E. (1989), Microwave Communications, Component and Circuit, McGraw Hill, New York.

Kraus, John, D. (1984), Electromagnetics, Third Edition, McGraw-Hill, New York.

Jurnal Sains dan Teknologi | 171 
Ohri, V, Amin, O, Gebremariam, H Dubois, B. (2003), Microwave Mikrostrip Horn Antena Design and Test System, San Jose State University.

Shafai. (2001), Microstrip Antena Design Handbook, Profesor University Of Manitoba, Wimmipeg, Canada.
Suherman, Nanang. (2008), Analisis dan Fabrikasi Antena Mikrostrip Horn dilengkapi Reflektor Parabola dengan Metode FDTD, Tugas Akhir, Jurusan Fisika Fakultas Matematika dan IImu Pengetahuan Alam, ITS, Surabaya.

Wikipedia. (2010), The free encyclopedia WIFI (AM). IEEE 802.11. 